\title{
Metabolism of Fenpropathrin (S-3206) in Rats
}

\author{
Hideo Kaneko, Kunio Shiba, Akira Yoshitake \\ and Junshi Miyamoto \\ Laboratory of Biochemistry and Toxicology, Takarazuka Research Center, \\ Sumitomo Chemical Co., Ltd., Takatsukasa, Takarazuka 665, Japan
}

(Received September 22, 1986)

\begin{abstract}
On single oral administration of each of ${ }^{14} \mathrm{C}$-acid- and ${ }^{14} \mathrm{C}$-alcohol-labeled preparations of fenpropathrin [(RS)- $\alpha$-cyano-3-phenoxybenzyl 2,2,3,3-tetramethylcyclopropanecarboxylate $]$ at 2.4 to $26.8 \mathrm{mg} / \mathrm{kg}$ to male and female SD rats, radiocarbon from the acid and alcohol moieties was almost completely eliminated within 7 days. Major excretion routes of the radiocarbon were the urine and feces. ${ }^{14} \mathrm{C}$ levels in tissue residues were generally very low with both labelings, although the levels were slightly higher in the fat $(0.1$ to $1.4 \mathrm{ppm})$. ${ }^{14} \mathrm{C}$ levels in tissue residues were generally lower with the alcohol-labeling than the acid-labeling. Main metabolites in the feces were ester derivatives, while those in the urine were ester-cleaved metabolites. Major metabolic reactions were oxidation at the $2^{\prime}$ - and $4^{\prime}$-positions of the alcohol moiety and at one or both of the geminal-methyl groups of the acid moiety, cleavage of the ester linkage, and conjugation of the resultant carboxylic acids and phenols with glucuronic acid, sulfuric acid and glycine. Sulfate of 3-(4'-hydroxyphenoxy)benzoic acid was a predominant metabolite derived from the alcohol moiety, accounting for 19 to $25 \%$ of the dose, whereas predominant metabolites from the acid moiety were 2,2,3,3-tetramethylcyclopropanecarboxylic acid, its hydroxylated derivatives and their glucuronides.
\end{abstract}

\section{INTRODUCTION}

Fenpropathrin[S-3206, Danitol ${ }^{\circledR}$, Meothrin ${ }^{\circledR}$, $(R S)$ - $\alpha$-cyano-3-phenoxybenzyl 2,2, 3, 3-tetramethylcyclopropanecarboxylate], one of the most potent pyrethroid insecticides, has been developed for agricultural use due to its high insecticidal activity toward a wide range of insect pests and mite as well as due to its toxicity acceptable to mammals. Photodegradation in water, on soils and on plant foliage, ${ }^{1)}$ hydrolysis in aqueous media ${ }^{2)}$ and metabolism in plants $^{3)}$ have already been reported. Besides metabolism of fenpropathrin (WL-41706) in rats was also investigated by Crawford and Hutson, ${ }^{4)}$ who reported that its major metabolic reactions are cleavage of the ester linkage, oxidation at the $4^{\prime}$-position of the alcohol moiety and at the trans-methyl group of the acid moiety, and conjugation of the resultant carboxylic acids and phenols with glucuronic acid, sulfuric acid or glycine. Their study, however, does not seem sufficient to elucidate the metabolic fate of this insecticide, particularly concerning tissue residues, blood levels, excretion patterns and identification of metabolites of the acid moiety.

This report deals with excretion, tissue residues, tissue levels of ${ }^{14} \mathrm{C}$ and amounts of metabolites in excreta and tissues after single oral administration of fenpropathrin labeled with ${ }^{14} \mathrm{C}$ in the acid or alcohol moiety or after single oral administration of the labeled acid moiety to rats.

\section{MATERIALS AND METHODS}

1. Designation of Compounds

Abbreviations used in this report are shown in Table 1.

\section{Chemicals}

Fenpropathrin labeled with ${ }^{14} \mathrm{C}$ at benzyl 
Table 1 Abbreviations of fenpropathrin and its derivatives.

\begin{tabular}{|c|c|}
\hline Abbreviation & Chemical structure \\
\hline Fenpropathrin & $\alpha$-Cyano-3-phenoxybenzyl 2,2,3,3-tetramethylcyclopropanecarboxylate \\
\hline $\mathrm{COOH}($ trans $)-\mathrm{Fenp}$. & $\begin{array}{l}\alpha \text {-Cyano-3-phenoxybenzyl 2-carboxy-2,2,3-trimethylcyclopropanecar- } \\
\text { boxylate }\end{array}$ \\
\hline 2'-OH-Fenp. & $\begin{array}{l}\alpha \text {-Cyano-3-(2'-hydroxyphenoxy) benzyl } 2,2,3,3 \text {-tetramethylcyclopro- } \\
\text { panecarboxylate }\end{array}$ \\
\hline $4^{\prime}-\mathrm{OH}-\mathrm{Fenp}$. & $\begin{array}{l}\alpha \text {-Cyano-3-(4'-hydroxyphenoxy) benzyl } 2,2,3,3 \text { - tetramethylcyclopro- } \\
\text { panecarboxylate }\end{array}$ \\
\hline $\mathrm{CH}_{2} \mathrm{OH}($ trans $)$-Fenp. & $\begin{array}{l}\alpha \text {-Cyano-3-phenoxybenzyl 2-hydroxymethyl-2,3,3-trimethylcyclopro- } \\
\text { panecarboxylate }\end{array}$ \\
\hline 2'-OH, $\mathrm{CH}_{2} \mathrm{OH}($ trans)-Fenp. & $\begin{array}{l}\alpha \text {-Cyano-3-(2'-hydroxyphenoxy) benzyl 2-hydroxymethyl-2,3,3-trimeth- } \\
\text { ylcyclopropanecarboxylate }\end{array}$ \\
\hline $4^{\prime}-\mathrm{OH}, \mathrm{CH}_{2} \mathrm{OH}($ trans $)-\mathrm{Fenp}$ & $\begin{array}{l}\alpha \text {-Cyano-3-(4'-hydroxyphenoxy) benzyl } 2 \text {-hydroxymethyl-2,3,3-trimeth- } \\
\text { ylcyclopropanecarboxylate }\end{array}$ \\
\hline TMPA & 2,2,3,3-Tetramethylcyclopropanecarboxylic acid \\
\hline TMPA- $\mathrm{CH}_{2} \mathrm{OH}($ trans $)$ & 2-Hydroxymethyl-2,3,3-trimethylcyclopropanecarboxylic acid \\
\hline TMPA-COOH $($ trans,cis $)$ & 2-Carboxy-2,3,3-trimethylcyclopropanecarboxylic acid \\
\hline TMPA-lactone & 5,6,6-Trimethyl-3-oxabicyclo[3.1.0]hexan-2-one \\
\hline TMPA- $\left(\mathrm{CH}_{2} \mathrm{OH}\right)_{2}$ & 2,2-Dihydroxymethyl-3,3-dimethylcyclopropanecarboxylic acid \\
\hline TMPA- $\mathrm{CH}_{2} \mathrm{OH}$-lactone & 5-Hydroxymethyl-6,6-dimethyl-3-oxabicyclo[3.1.0]hexan-2-one \\
\hline PBald & 3-Phenoxybenzaldehyde \\
\hline 2'-OH-PBacid & 3-(2'-Hydroxyphenoxy) benzoic acid \\
\hline $4^{\prime}-\mathrm{OH}-\mathrm{PBacid}$ & 3-(4'-Hydroxyphenoxy) benzoic acid \\
\hline PBacid & 3-Phenoxybenzoic acid \\
\hline PBacid-glycine & $N$-3-Phenoxybenzoyl-glycine \\
\hline
\end{tabular}

carbon of the alcohol moiety $\left({ }^{14} \mathrm{C}\right.$-alcohol) or at the $\mathrm{C}(1)$ position of the cyclopropane ring of the acid moiety $\left({ }^{14} \mathrm{C}\right.$-acid $)$, and TMPA labeled at the $\mathrm{C}(1)$ position of the cyclopropane ring were synthesized in this laboratory. ${ }^{5)}$ The labeling positions and specific activities of these labeled preparations are listed in Table 2. These labeled preparations were purified by thin-layer chromatography (TLC) using $n$-hexane-acetone (4/1) or chloroform-methanol (9/1) as a solvent system prior to treatment. Purified preparations were radiochemically more than $99 \%$ pure, when determined on TLC by using benzene or $n$-hexane-toluene-acetic acid (3/ $15 / 2$ ) as a solvent system. Unlabeled fenpropathrin was also used in this study with its chemical purity more than $99 \%$.

The preparations of unlabeled authentic standards used in this study were reported previously. ${ }^{3,6-8)}$

\section{Thin-layer Chromatography (TLC)}

Precoated silica gel $60 \mathrm{~F}_{254}$ chromatoplates $(20 \times 20 \mathrm{~cm}, \quad 0.25 \mathrm{~mm}$ layer thickness, E.
Table 2 Labeled positions and specific activities of ${ }^{14} \mathrm{C}$-labeled preparations of fenpropathrin and TMPA.

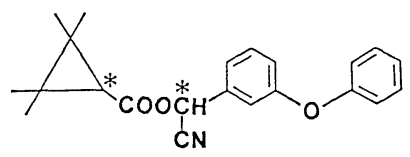

Fenpropathrin

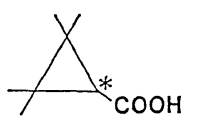

TMPA * Labeled carbon.

Specific activity $(\mathrm{mCi} / \mathrm{mmol})$

\begin{tabular}{ccc}
\hline \multirow{2}{*}{ TMPA } & \multicolumn{2}{c}{ Fenpropathrin } \\
\cline { 2 - 3 } & Acid-labeling & Alcohol-labeling \\
\hline 25.6 & 33.8 & 24.5 \\
\hline
\end{tabular}

Merck) were used for both analysis and separation of metabolites. Solvent systems used were; A) $n$-hexane-toluene-acetic acid (3/15/2, 
Table $3 R f$ values of fenpropathrin and its derivatives on TLC.

\begin{tabular}{|c|c|c|c|c|}
\hline \multirow{2}{*}{ Chemical } & \multicolumn{4}{|c|}{$R f$ value with indicated solvent systems } \\
\hline & A & $\mathrm{A}^{\prime}$ & B & $\mathrm{C}$ \\
\hline Fenpropathrin & 0.89 & 0.57 & 0.94 & 0.89 \\
\hline \multirow[t]{2}{*}{$\mathrm{COOH}($ trans $)$-Fenp. } & 0.61 & 0.35 & 0.78 & 0.61 \\
\hline & 0.59 & & 0.75 & \\
\hline 2'-OH-Fenp. & 0.61 & 0.41 & 0.88 & 0.85 \\
\hline $4^{\prime}-\mathrm{OH}-\mathrm{Fenp}$ & 0.42 & 0.27 & 0.78 & 0.65 \\
\hline \multirow[t]{2}{*}{$\mathrm{CH}_{2} \mathrm{OH}($ trans $)$-Fenp. } & 0.45 & 0.25 & 0.59 & 0.62 \\
\hline & 0.42 & & 0.56 & \\
\hline 2'-OH, $\mathrm{CH}_{2} \mathrm{OH}$-Fenp. & 0.22 & 0.05 & 0.43 & 0.44 \\
\hline $4^{\prime}-\mathrm{OH}, \mathrm{CH}_{2} \mathrm{OH}-\mathrm{Fenp}$. & 0.12 & 0.04 & 0.37 & 0.43 \\
\hline TMPA & 0.70 & 0.36 & 0.77 & 0.71 \\
\hline TMPA- $\mathrm{CH}_{2} \mathrm{OH}$ (trans) & 0.25 & 0.15 & 0.29 & 0.34 \\
\hline TMPA-lactone & 0.63 & 0.26 & 0.66 & 0.62 \\
\hline TMPA- $\left(\mathrm{CH}_{2} \mathrm{OH}\right)_{2}$ & 0.03 & 0.01 & 0.06 & 0.31 \\
\hline TMPA- $\mathrm{CH}_{2} \mathrm{OH}$-lactone & 0.06 & 0.03 & 0.13 & 0.28 \\
\hline \multirow{2}{*}{$\begin{array}{ll}\text { TMPA-COOH } & (\text { cis }) \\
& (\text { trans })\end{array}$} & 0.14 & 0.17 & 0.26 & 0.35 \\
\hline & 0.40 & 0.15 & 0.45 & 0.34 \\
\hline PBacid & 0.61 & & 0.70 & 0.63 \\
\hline 2'-OH-PBacid & 0.44 & & 0.50 & 0.54 \\
\hline $4^{\prime}-\mathrm{OH}-\mathrm{PBacid}$ & 0.30 & & 0.47 & 0.51 \\
\hline PBacid-glycine & 0.06 & & 0.06 & \\
\hline
\end{tabular}

two developments), $\mathrm{A}^{\prime}$ ) $n$-hexane-tolueneacetic acid (3/15/2), B) benzene saturated with formic acid-diethyl ether (10/3, two developments), C) toluene-ethyl formate-formic acid $(5 / 7 / 1)$, D) $n$-butanol-acetic acid-water $(6 / 1 / 1)$.

$R f$ values with solvent systems $\mathrm{A}, \mathrm{A}^{\prime}, \mathrm{B}$ and $\mathrm{C}$ for authentic standards are shown in Table 3. Unlabeled standards of the ester derivatives and the alcohol moiety were visualized under ultraviolet light. Unlabeled standards of the acid moiety were located by spraying an ethanol solution of phosphomolybdic acid $(20 \%)^{9)}$ or a methanol solution of bromo cresol green $(0.3 \%)$ and then heating. Radioactive spots on developed TLC plates were detected by placing X-ray film (SB-5, Kodak) on the plates at $4-8^{\circ} \mathrm{C}$ for about 1 week, followed by processing the exposed film.

\section{Radioanalysis and Autoradiography}

Liquid scintillation counting (LSC), combustion analysis, ${ }^{14} \mathrm{CO}_{2}$ determination and TLC autoradiography were conducted as previously reported..$^{9)}$

\section{Treatment of Rats}

Charles River (CD)-derived Sprague-Dawley male and female rats at the age of 6 weeks old were purchased from Charles River, Japan, and allowed about a week to adjust to the environment.

Room conditions were as follows: light cycle, light 8:00 AM-8:00 PM, dark 8:00 PM-8: $00 \mathrm{AM}$; room temperature, $25 \pm 2{ }^{\circ} \mathrm{C}$; and humidity, $55 \pm 10 \%$.

\subsection{Preliminary study}

Each of the acid- or alcohol-labeled preparations of fenpropathrin was dissolved in corn oil immediately prior to treatment throughout the present study. Three male rats were treated with a single oral dose of each of the labeled preparations at 2.2 to $2.8 \mathrm{mg} / \mathrm{kg}$. The administered volume of the corn oil was $5 \mathrm{ml} /$ $\mathrm{kg}$ throughout the present study.

\subsection{Low-dose groups}

Five male and five female rats were treated with a single oral dose of each of the labeled preparations at 2.4 to $3.8 \mathrm{mg} / \mathrm{kg}$.

\subsection{High-dose groups}

Each of the labeled preparations of fenpro- 
pathrin was diluted with unlabeled fenpropathrin to give preparations with appropriate specific activities $(3.1-6.7 \mathrm{mCi} / \mathrm{mmol})$. Five male and five female rats were treated with a single oral dose of each of the labeled preparations at 18.5 to $26.8 \mathrm{mg} / \mathrm{kg}$.

\section{$5.4{ }^{14} C$-TMPA-dose groups}

${ }^{14} \mathrm{C}$-TMPA was orally administered to three male rats at 1.0 to $1.1 \mathrm{mg} / \mathrm{kg}$ (ca. $2.5 \mathrm{mg} / \mathrm{kg}$ fenpropathrin equivalent).

The treated animals were individually held in all-glass metabolism cages (Metabolica CO$2^{\circledR}$, Sugiyamagen Iriki Co., Ltd., Tokyo, Japan), and their urine and feces were separately collected for 7 days. Expired air from rats treated with both labelings in the preliminary study was trapped in $400 \mathrm{ml}$ of $10 \% \mathrm{NaOH}$ solution. The air-flow rate through the cage was 200 to $300 \mathrm{ml} / \mathrm{min}$. The rats were given a diet (CE-2, Clea Japan, Inc., Japan) and water ad libitum during the experiments.

The treated animals (5. 1-4 groups) were sacrificed 7 days after administration and 20 to 21 tissues were excised to be analyzed for total radiocarbon by combustion and LSC. Rat carcass was minced on a meat chopper (Model MS-12, Nantsune Co., Ltd., Japan). One or two samples from each tissue were subjected to combustion analysis for ${ }^{14} \mathrm{C}$ determination. Tissue residue levels are given as parts per billion equivalents (ppb) of the administered ${ }^{14} \mathrm{C}$-labeled preparations based on the wet tissue weight.

\subsection{Distribution study}

${ }^{14} \mathrm{C}$-Acid-fenpropathrin was dissolved in corn oil, and male rats were treated with a single oral dose at 2.0 to $2.7 \mathrm{mg} / \mathrm{kg}$. Three of the treated rats were sacrificed at appropriate intervals, and the blood, liver and kidney were removed for determination of total ${ }^{14} \mathrm{C}$ levels, identification of metabolites and quantification of fenpropathrin and TMPA. Tissue levels of ${ }^{14} \mathrm{C}$, fenpropathrin and TMPA are given as parts per billion equivalents (ppb) of the administered ${ }^{14} \mathrm{C}$-labeled preparations.

\subsection{Characterization of ${ }^{14} \mathrm{C}$ in fat}

Five male rats were pretreated with consecutive oral doses of unlabeled fenpropathrin at $2.5 \mathrm{mg} / \mathrm{kg} /$ day for 14 days and within $24 \mathrm{hr}$ after the last shot they were given a single oral dose of ${ }^{14} \mathrm{C}$-alcohol- and acid-fenpropathrin at
2.3 to $3.0 \mathrm{mg} / \mathrm{kg}$. The treated rats were sacrificed after 7 days and the fat was excised and subjected to analysis for characterization of residual metabolites.

\section{Analysis of Excreta and Tissues}

Aliquots of the urine were analyzed directly by LSC. The 0-2 day urine was combined and subjected to TLC analysis.

The 0-2 day feces were extracted three times with methanol-water $(8 / 2)$, and the extracts and residues were radioassayed. Methanol extracts of the $0-2$ day feces were combined and then subjected to TLC analysis after concentration by a rotary evaporator at $37^{\circ} \mathrm{C}$. The 3-7 day feces were homogenized with water by a Polytron (Kinematica, Sweden) and the aliquots of the homogenates were combusted prior to LSC.

The tissues were homogenized in three-fold volumes of saline by a Polytron and the aliquots were subjected to combustion analysis for determination of total ${ }^{14} \mathrm{C}$ levels. Thereafter, the tissue homogenates were mixed with methanol, shaken with a shaker (Iwaki Co., Ltd., Japan) for $10 \mathrm{~min}$ and centrifuged at $3000 \mathrm{rpm}$ for $10 \mathrm{~min}$. The procedure was repeated twice. The obtained supernatants were combined and concentrated, and the extracted metabolites were subjected to TLC analysis.

Metabolites in the fat of male rats were extracted with $n$-hexane-acetonitrile (1/1). Each of the $n$-hexane and acetonitrile layers was radioassayed, and thereafter the acetonitrile layer was subjected to TLC analysis.

\section{Identification of Metabolites in Excreta and Tissues}

Methanol extracts of the 0-2 day feces were subjected to TLC with solvent system A. The 0-2 day urine was directly subjected to TLC analysis with solvent systems B and D. Methanol extracts of the tissues were subjected to TLC analysis with solvent systems B and D. Each of the urinary, fecal and tissue metabolites detected by autoradiography was extracted with methanol from gel regions and subjected to TLC cochromatography with solvent systems $\mathrm{A}, \mathrm{B}$ and $\mathrm{C}$ with appropriate authentic standards. Metabolites retaining the 
ester linkage were recognized by comparing the chromatographic locations of the metabolites from the acid-labeling with those from the alcohol-labeling.

After TLC analysis of the urine with solvent system B, the silica gel at the origin of TLC plates was scraped out and extracted with methanol. Subsequently the extract was analyzed by TLC with solvent system D. Individual conjugates were subjected to enzyme hydrolysis; each conjugate was incubated with $\beta$-glucuronidase (bovine liver, Type B-1, Sigma) or sulfatase (limpets, Type IV, Sigma) in $1 \mathrm{ml}$ of $0.2 \mathrm{M}$ acetate buffer $(\mathrm{pH} 5.0)$ at $37^{\circ} \mathrm{C}$ overnight. Saccharo-1,4-lactone, an inhibitor of $\beta$-glucuronidase, was added to the incubation mixture in the case of hydrolysis by sulfatase. The aglycones released were extracted twice with three-fold volumes of diethyl etherethanol (2/1) after acidification of the incubation mixture with $1 \mathrm{~N} \mathrm{HCl}$. Each of the aglycones was identified tentatively by TLC cochromatography with solvent systems A, B and $\mathrm{C}$.

\section{RESULTS}

1. ${ }^{14} C$ Excretion

The preliminary study revealed that no
${ }^{14} \mathrm{CO}_{2}$ was substantially exhaled from rats through initial $48 \mathrm{hr}$ after administration of ${ }^{14} \mathrm{C}$-acid or ${ }^{14} \mathrm{C}$-alcohol-fenpropathrin; in fact, only $0.3 \%$ and $<0.1 \%$ of the dosed ${ }^{14} \mathrm{C}$ were recovered for the acid- and alcohol-labelings, respectively. Single oral administration of ${ }^{14} \mathrm{C}$ acid- and ${ }^{14} \mathrm{C}$-alcohol-fenpropathrin to male and female rats at 2.4 to $26.8 \mathrm{mg} / \mathrm{kg}$ resulted in rapid and almost complete elimination of radiocarbon from the animal bodies. As shown in Table 4 , total ${ }^{14} \mathrm{C}$ recoveries for the acidand alcohol-labelings in the two dose groups were 96.4 to $101.9 \%$ (urine; 26.8 to $43.8 \%$ and feces; 58.1 to $70.4 \%$ ) and 96.4 to $98.0 \%$ (urine; 26.0 to $42.7 \%$ and feces; 54.1 to $71.0 \%$ ), respectively. ${ }^{14} \mathrm{C}$ excretion patterns of both labeled preparations into the urine and feces were very similar in the two dose groups. Fecal ${ }^{14} \mathrm{C}$ excretion was larger in the high-dose groups than in the low-dose groups. There was no significant sex difference in the excretion patterns. When rats were orally dosed with ${ }^{14} \mathrm{C}-\mathrm{TMPA}$, radiocarbon was rapidly excreted mainly into the urine (88\% of the dose) (Table 4).

\section{Tissue Residues}

Table 5 shows ${ }^{14} \mathrm{C}$ residue levels in the tis-

Table $4{ }^{14} \mathrm{C}$ recovery during 7 days after single oral administration of ${ }^{14} \mathrm{C}$-acid- or ${ }^{14} \mathrm{C}$-alcoholfenpropathrin at 2.4 to $26.8 \mathrm{mg} / \mathrm{kg}$ and of ${ }^{14} \mathrm{C}-\mathrm{TMPA}$ at 1.0 to $1.1 \mathrm{mg} / \mathrm{kg}$ to male and female rats.

\begin{tabular}{|c|c|c|c|c|}
\hline \multirow{2}{*}{ Dose group } & \multirow{2}{*}{ Sex } & \multicolumn{3}{|c|}{${ }^{14} \mathrm{C}$ total recovery $\left.\left(\% \text { of the dose }{ }^{14} \mathrm{C}\right)^{a}\right)$} \\
\hline & & Total & Urine & Feces \\
\hline \multicolumn{5}{|c|}{${ }^{14} \mathrm{C}$-Acid-fenpropathrin ${ }^{\mathrm{b}}$ ) } \\
\hline \multirow[t]{2}{*}{ Low dose } & Male & $96.4 \pm 3.6$ & $(35.0 \pm 10.2$ & $61.4 \pm 10.8)$ \\
\hline & Female & $101.9 \pm 1.7$ & $(43.8 \pm 8.8$ & $58.1 \pm 9.4)$ \\
\hline \multirow[t]{2}{*}{ High dose } & Male & $97.2 \pm 1.6$ & $(26.8 \pm 4.4$ & $70.4 \pm 4.0)$ \\
\hline & Female & $99.3 \pm 1.6$ & $(31.8 \pm 5.3$ & $67.5 \pm 4.4)$ \\
\hline \multicolumn{5}{|c|}{${ }^{14} \mathrm{C}$-Alcohol-fenpropathrin ${ }^{\mathrm{b})}$} \\
\hline \multirow[t]{2}{*}{ Low dose } & Male & $96.4 \pm 1.5$ & $(33.7 \pm 7.3$ & $62.7 \pm 7.1)$ \\
\hline & Female & $96.8 \pm 3.5$ & $(42.7 \pm 7.2$ & $54.1 \pm 8.8)$ \\
\hline \multirow[t]{2}{*}{ High dose } & Male & $97.0 \pm 2.9$ & $(26.0 \pm 3.2$ & $71.0 \pm 2.5)$ \\
\hline & Female & $98.0 \pm 7.1$ & $(36.0 \pm 10.2$ & $62.0 \pm 12.7)$ \\
\hline \multicolumn{5}{|l|}{$\left.{ }^{14} \mathrm{C}-\mathrm{TMPA}{ }^{\mathrm{c}}\right)$} \\
\hline & Male & $99.9 \pm 1.2$ & $(88.3 \pm 7.9$ & $11.6 \pm 6.7)$ \\
\hline
\end{tabular}

a) A preliminary study showed that ${ }^{14} \mathrm{C}$ excretion into expired air was $0.3 \%$ and $<0.1 \%$ of the dose with ${ }^{14} \mathrm{C}$-acid- and ${ }^{14} \mathrm{C}$-alcohol-fenpropathrin, respectively.

b) Mean values \pm S.D. of five rats.

c) Mean values \pm S.D. of three rats. 
Table $5{ }^{14} \mathrm{C}$ tissue residues 7 days after single oral administration of ${ }^{14} \mathrm{C}$-acid- or ${ }^{14} \mathrm{C}$-alcoholfenpropathrin to male (and female) SD rats at 2.4 to $26.8 \mathrm{mg} / \mathrm{kg}$.

\begin{tabular}{|c|c|c|c|c|}
\hline \multirow{3}{*}{ Tissue $^{a}$ ) } & \multicolumn{4}{|c|}{ ng fenpropathrin eq./g wet tissue ${ }^{b}$ ) } \\
\hline & \multicolumn{2}{|c|}{ Acid-labeling } & \multicolumn{2}{|c|}{ Alcohol-labeling } \\
\hline & Low dose & High dose & Low dose & High dose \\
\hline Adrenal & $8 \pm 1$ & -c) & - & - \\
\hline Blood & $11 \pm 4$ & $28 \pm 6$ & - & - \\
\hline Brain & $2 \pm 1$ & - & - & - \\
\hline Fat & $98 \pm 19$ & $425 \pm 218$ & $173 \pm 71$ & $1372 \pm 433$ \\
\hline Heart & $7 \pm 2$ & - & - & - \\
\hline Kidney & $58 \pm 18$ & $129 \pm 24$ & - & - \\
\hline Liver & $16 \pm 10$ & $70 \pm 17$ & $6 \pm 2$ & $28 \pm 12$ \\
\hline Lung & $10 \pm 2$ & $31 \pm 11$ & - & - \\
\hline Ovaryd $^{d}$ & $6 \pm 4$ & $125 \pm 44$ & $50 \pm 25$ & $56 \pm 51$ \\
\hline Skin & $14 \pm 4$ & $63 \pm 22$ & $3 \pm 2$ & $49 \pm 22$ \\
\hline Spleen & $7 \pm 2$ & - & - & 一 \\
\hline Testis & $5 \pm 3$ & - & - & 一 \\
\hline Uterus $^{d}$ ) & $5 \pm 2$ & $80 \pm 66$ & $34 \pm 34$ & - \\
\hline Carcass & $11 \pm 4$ & $72 \pm 23$ & $11 \pm 7$ & $82 \pm 48$ \\
\hline
\end{tabular}

a) ${ }^{14} \mathrm{C}$ tissue residues were generally lower in bone, caecum, intestine, muscle, pancreas, sciatic nerve, spinal cord and stomach than tissues listed in this table.

b) Mean values of five animals \pm S.D.

c) Below the detection limit.

d) Of female rats.

sues of male rats (ovary and uterus of female rats) 7 days after single oral administration of both labelings at two dose levels, because there was no apparent sex difference in ${ }^{14} \mathrm{C}$ tissue residues. Tissue residue levels were very low in the two dose groups although the fat showed slightly higher residue levels (98-1372 ppb) than other analyzed tissues. The alcohollabeling showed slightly lower residue levels in all tissues, except in the fat, than the acidlabeling.

Residue levels in the fat were 2 to 3 times higher with the alcohol-labeling than with the acid-labeling. To characterize the residual radiocarbon in the fat, the radiocarbon in the fat of rats pretreated with unlabeled fenpropathrin was extracted with $n$-hexane-acetonitrile (1/1). The amount of the radiocarbon distributed in the $n$-hexane layer was about 3 times larger with the alcohol-labeling than with the acid moiety, while the radiocarbon level in the acetonitrile layer was nearly the same with the acid-labeling and with the alcohol-labelng (Table 6). TLC analysis of the acetonitrile
Table 6 Distribution of ${ }^{14} \mathrm{C}$ in the fat of male rats into $n$-hexane and acetonitrile.

\begin{tabular}{lcc}
\hline & \multicolumn{2}{c}{$\begin{array}{c}\text { ng fenpropathrin } \\
\text { eq./g wet fat }\end{array}$} \\
\cline { 2 - 3 } & $\begin{array}{c}\text { Acid- } \\
\text { labeling }\end{array}$ & $\begin{array}{c}\text { Alcohol- } \\
\text { labeling }\end{array}$ \\
\hline Total ${ }^{14} \mathrm{C}$ & 132 & 232 \\
$n$-Hexane layer & 32 & 95 \\
Acetonitrile layer & $100(97)^{\text {a })}$ & $137(122)$ \\
Unextractable ${ }^{14} \mathrm{C}$ & ${ }^{\text {b) }}$ & - \\
\hline a) Figures in the parentheses show the amount \\
of parent compound.
\end{tabular}

layer revealed that the major metabolite was the unchanged parent compound, with the concentration being $97 \mathrm{ppb}$ with the acidlabeling and $122 \mathrm{ppb}$ with the alcohol-labeling.

\section{Tissue Levels}

In rats treated with a single oral dose of 
Table 7 Tissue levels of total ${ }^{14} \mathrm{C}$, fenpropathrin and TMPA in the liver, kidney and blood of male SD rats given a single oral dose of ${ }^{14} \mathrm{C}$-acid-fenpropathrin at 2.0 to $2.7 \mathrm{mg} / \mathrm{kg}$.

\begin{tabular}{|c|c|c|c|c|c|c|}
\hline \multirow{2}{*}{ Tissue } & \multicolumn{6}{|c|}{ ng fenpropathrin eq./g wet tissue } \\
\hline & 1 & 3 & 6 & 12 & 24 & $48 \mathrm{hr}$ \\
\hline \multicolumn{7}{|l|}{ Blood } \\
\hline Total $\left.{ }^{14} \mathrm{C}^{\mathrm{a}}\right)$ & $34 \pm 5$ & $79 \pm 8$ & $118 \pm 56$ & $81 \pm 11$ & $31 \pm 4$ & $15 \pm 3$ \\
\hline Fenpropathrin ${ }^{b}$ ) & 8 & 13 & 14 & 2 & 2 & -c) \\
\hline $\mathrm{TMPA}^{\mathrm{b}}$ ) & 4 & 7 & 10 & 9 & - & - \\
\hline \multicolumn{7}{|l|}{ Kidney } \\
\hline Total ${ }^{14} \mathrm{C}$ & $44 \pm 11$ & $102 \pm 16$ & $370 \pm 222$ & $256 \pm 59$ & $90 \pm 30$ & $42 \pm 11$ \\
\hline Fenpropathrin & 9 & 20 & 79 & 33 & 7 & 2 \\
\hline TMPA & 3 & 4 & 11 & 9 & - & - \\
\hline \multicolumn{7}{|l|}{ Liver } \\
\hline Total ${ }^{14} \mathrm{C}$ & $130 \pm 32$ & $297 \pm 32$ & $450 \pm 255$ & $242 \pm 34$ & $108 \pm 22$ & $42 \pm 13$ \\
\hline Fenpropathrin & 12 & $\overline{15}$ & $\overline{46}$ & 9 & 6 & 2 \\
\hline TMPA & 8 & 25 & 19 & 11 & 4 & - \\
\hline
\end{tabular}

a) Mean values of three rats \pm S.D.

b) Tissue levels of fenpropathrin and TMPA were determined after combining the tissues of three rats.

c) Below the detection limit (2 ppb).

${ }^{14} \mathrm{C}$-acid-fenpropathrin, total ${ }^{14} \mathrm{C}$ levels in the blood, liver and kidney reached maxima within $6 \mathrm{hr}$ after administration and rapidly decreased thereafter (Table 7). The maximum levels were 118,370 and $450 \mathrm{ppb}$ in the blood, kidney and liver, respectively. Levels of fenpropathrin and TMPA, the two major components of ${ }^{14} \mathrm{C}$ in these tissues, also reached maxima within $6 \mathrm{hr}$ and then rapidly decreased (Table 7).

\section{Amounts of Metabolites in Excreta}

Table 8 shows the amounts of ${ }^{14} \mathrm{C}$ metabolites in the feces and urine collected from male rats dosed with ${ }^{14} \mathrm{C}$-acid- and ${ }^{14} \mathrm{C}$-alcohol-fenpropathrin. The metabolites were tentatively identified by TLC cochromatography with the authentic standards. As there was no apparent sex difference, the data on male rats are shown in Table 8.

Almost all fecal metabolites retained the ester linkage; the parent fenpropathrin and at least six ester metabolites were found in the feces. The amount of the parent compound was larger in the high-dose groups (48.2 to $53.0 \%$ of the dose) than in the low-dose groups (29.2 to $35.5 \%$ of the dose). The ester metabolites were derived from combination of the acid oxidized at the methyl group of the cyclopro- pane ring and/or the alcohol oxidized at the $4^{\prime}$-position of the phenoxy ring. Among the identified ester metabolites, $\mathrm{CH}_{2} \mathrm{OH}($ trans)fenpropathrin was the largest in amount (4.5 to $7.9 \%$ of the dose), followed by $\mathrm{COOH}($ trans)fenpropathrin, 4'-OH-fenpropathrin and 4'$\mathrm{OH}-, \mathrm{CH}_{2} \mathrm{OH}$ (trans)-fenpropathrin.

On the other hand, most of the urinary metabolites were ester-cleaved ones. The major urinary metabolites derived from the alcohol moiety were PBacid and 4'-OH-PBacid in free and sulfate forms. 4'-OH-PBacid-sulfate accounted for 18.7 to $24.8 \%$ of the dose. Other identified metabolites were PBacid-glycine and 2'-OH-PBacid-sulfate and their amounts ranged from 0.5 to $0.9 \%$ of the dose.

The most predominant metabolite derived from the acid moiety was TMPA-glucuronide, which accounted for 8.6 to $10.3 \%$ of the dose. Other metabolites identified were TMPA$\mathrm{COOH}($ trans $)$, TMPA- $\mathrm{CH}_{2} \mathrm{OH}$ (trans) and TMPA- $\mathrm{CH}_{2} \mathrm{OH}$-lactone in free and glucuronide forms.

As shown in Table 9, TMPA, TMPA- $\mathrm{CH}_{2} \mathrm{OH}$ (trans) and their glucuronides were detected in the urine and feces of rats treated with ${ }^{14} \mathrm{C}$ TMPA. However, TMPA-COOH(trans), TMPA- $\mathrm{CH}_{2} \mathrm{OH}$-lactone and their glucuronides 
Table 8 Amounts of metabolites in the 0-2 day excreta after single oral administration of ${ }^{14} \mathrm{C}$-acid- or ${ }^{14} \mathrm{C}$-alcohol-fenpropathrin to male $\mathrm{SD}$ rats at 2.4 to $25.3 \mathrm{mg} / \mathrm{kg}$.

\begin{tabular}{|c|c|c|c|c|}
\hline \multirow{3}{*}{ Metabolite } & \multicolumn{4}{|c|}{$\%$ of the dosed $\left.{ }^{14} \mathrm{C}^{\mathrm{a}}\right)$} \\
\hline & \multicolumn{2}{|c|}{ Acid-labeling } & \multicolumn{2}{|c|}{ Alcohol-labeling } \\
\hline & Low dose & High dose & Low dose & High dose \\
\hline & \multicolumn{4}{|c|}{ Feces } \\
\hline \multicolumn{5}{|l|}{ Organosoluble fraction } \\
\hline Fenpropathrin & $35.5 \pm 13.0$ & $48.2 \pm 8.8$ & $29.2 \pm 11.6$ & $53.0 \pm 4.2$ \\
\hline PBald & & & $0.3 \pm 0.1$ & $0.3 \pm 0.1$ \\
\hline PBacid & & & $0.7 \pm 0.5$ & $0.1 \pm 0.1$ \\
\hline $\mathrm{COOH}($ trans $)-\mathrm{Fenp}$. & $1.5 \pm 0.3$ & $1.3 \pm 0.4$ & $1.9 \pm 0.4$ & $1.0 \pm 0.1$ \\
\hline $4^{\prime}-\mathrm{OH}-\mathrm{Fenp}$ & $2.3 \pm 1.8$ & $1.8 \pm 0.5$ & $2.0 \pm 1.0$ & $1.0 \pm 0.4$ \\
\hline $\mathrm{CH}_{2} \mathrm{OH}($ trans $)-\mathrm{Fenp}$ & $4.5 \pm 2.0$ & $6.2 \pm 1.9$ & $7.9 \pm 1.8$ & $5.3 \pm 0.6$ \\
\hline $4^{\prime}-\mathrm{OH}-, \mathrm{COOH}($ trans $)-\mathrm{Fenp}$. & $1.9 \pm 0.5$ & $1.4 \pm 0.4$ & $2.3 \pm 0.6$ & $1.3 \pm 0.2$ \\
\hline Others & $8.9 \pm 3.0$ & $7.2 \pm 2.3$ & $12.2 \pm 6.0$ & $4.9 \pm 0.8$ \\
\hline Unextractable ${ }^{14} \mathrm{C}$ & $3.0 \pm 0.5$ & $3.1 \pm 1.0$ & $4.4 \pm 1.0$ & $2.8 \pm 0.4$ \\
\hline Total & $57.6 \pm 11.5$ & $69.2 \pm 4.4$ & $60.8 \pm 8.1$ & $69.7 \pm 2.7$ \\
\hline \multicolumn{5}{|c|}{ Urine } \\
\hline PBacid & & & $2.0 \pm 0.6$ & $2.3 \pm 0.2$ \\
\hline glycine & & & $0.9 \pm 0.2$ & $0.8 \pm 0.2$ \\
\hline 4'-OH-PBacid sulfate & & & $24.8 \pm 5.0$ & $18.7 \pm 2.3$ \\
\hline 2'-OH-PBacid sulfate & & & $0.9 \pm 0.3$ & $0.5 \pm 0.1$ \\
\hline TMPA free & $0.4 \pm 0.2$ & $0.4 \pm 0.4$ & & \\
\hline glucuronide & $10.3 \pm 3.1$ & $8.6 \pm 2.2$ & & \\
\hline TMPA-COOH(trans) & $2.1 \pm 0.6$ & $1.4 \pm 0.3$ & & \\
\hline TMPA- $\mathrm{CH}_{2} \mathrm{OH}$ free & $5.4 \pm 1.8$ & $3.8 \pm 0.5$ & & \\
\hline (trans) $\quad$ glucuronide & $0.7 \pm 0.2$ & $0.6 \pm 0.1$ & & \\
\hline TMPA- $\mathrm{CH}_{2} \mathrm{OH}-$ free & $1.2 \pm 0.4$ & $1.1 \pm 0.3$ & & \\
\hline lactone glucuronide & $1.6 \pm 0.5$ & $1.4 \pm 0.4$ & & \\
\hline Others & $11.7 \pm 3.6$ & $8.5 \pm 1.5$ & $4.0 \pm 1.1$ & $2.9 \pm 0.5$ \\
\hline Total & $33.4 \pm 9.8$ & $25.8 \pm 4.1$ & $32.6 \pm 6.8$ & $25.2 \pm 3.1$ \\
\hline
\end{tabular}

a) Mean values of five animals \pm S.D.

Table 9 Amounts of metabolites in the $0-2$ day excreta after single oral administration of ${ }^{14} \mathrm{C}$ TMPA to male SD rats at 1.0 to $1.1 \mathrm{mg} / \mathrm{kg}$.

\begin{tabular}{|c|c|c|}
\hline \multicolumn{2}{|l|}{ Metabolite } & $\begin{array}{l}\% \text { of the } \\
\left.\text { dosed }{ }^{14} \mathrm{C}^{\mathrm{a}}\right)\end{array}$ \\
\hline & & Feces \\
\hline \multicolumn{3}{|c|}{ Organosoluble fractions } \\
\hline \multicolumn{2}{|c|}{ TMPA } & $5.1 \pm 3.9$ \\
\hline \multicolumn{2}{|c|}{ TMPA- $\mathrm{CH}_{2} \mathrm{OH}$ (trans) } & $4.0 \pm 1.7$ \\
\hline \multicolumn{2}{|c|}{ Others } & $1.7 \pm 1.0$ \\
\hline \multicolumn{2}{|l|}{ Unextractable ${ }^{14} \mathrm{C}$} & $0.4 \pm 0.1$ \\
\hline \multicolumn{2}{|l|}{ Total } & $11.2 \pm 6.6$ \\
\hline \multirow{3}{*}{ TMPA } & & Urine \\
\hline & free & $2.8 \pm 2.1$ \\
\hline & glucuronide & $62.0 \pm 10.0$ \\
\hline TMPA-CH${ }_{2} \mathrm{OH}$ & free & $11.3 \pm 3.6$ \\
\hline (trans) & glucuronide & $6.7 \pm 1.4$ \\
\hline Others & & $4.6 \pm 0.7$ \\
\hline Total & & $87.4 \pm 8.1$ \\
\hline
\end{tabular}

a) Mean values of three animals \pm S.D. were hardly detected in the excreta.

\section{DISCUSSION}

The preliminary study showed that no volatile radioactive material was exhaled during the period of $0-48 \mathrm{hr}$ after dosing, which is in accordance with the study by Crawford and Hutson.4) On single oral administration of each of ${ }^{14} \mathrm{C}$ acid- and ${ }^{14} \mathrm{C}$-alcohol-fenpropathrin to male and female SD rats at 2.4 to $26.8 \mathrm{mg} / \mathrm{kg}$, radiocarbon from the acid and alcohol moieties was almost completely eliminated into the urine and feces within 7 days. The major excretion routes of ${ }^{14} \mathrm{C}$ were the urine and feces. The ${ }^{14} \mathrm{C}$ tissue residue levels were generally very low. No significant sex differences were observed in the ${ }^{14} \mathrm{C}$ excretion patterns and ${ }^{14} \mathrm{C}$ tissue residues.

The fat showed slightly higher residue levels 


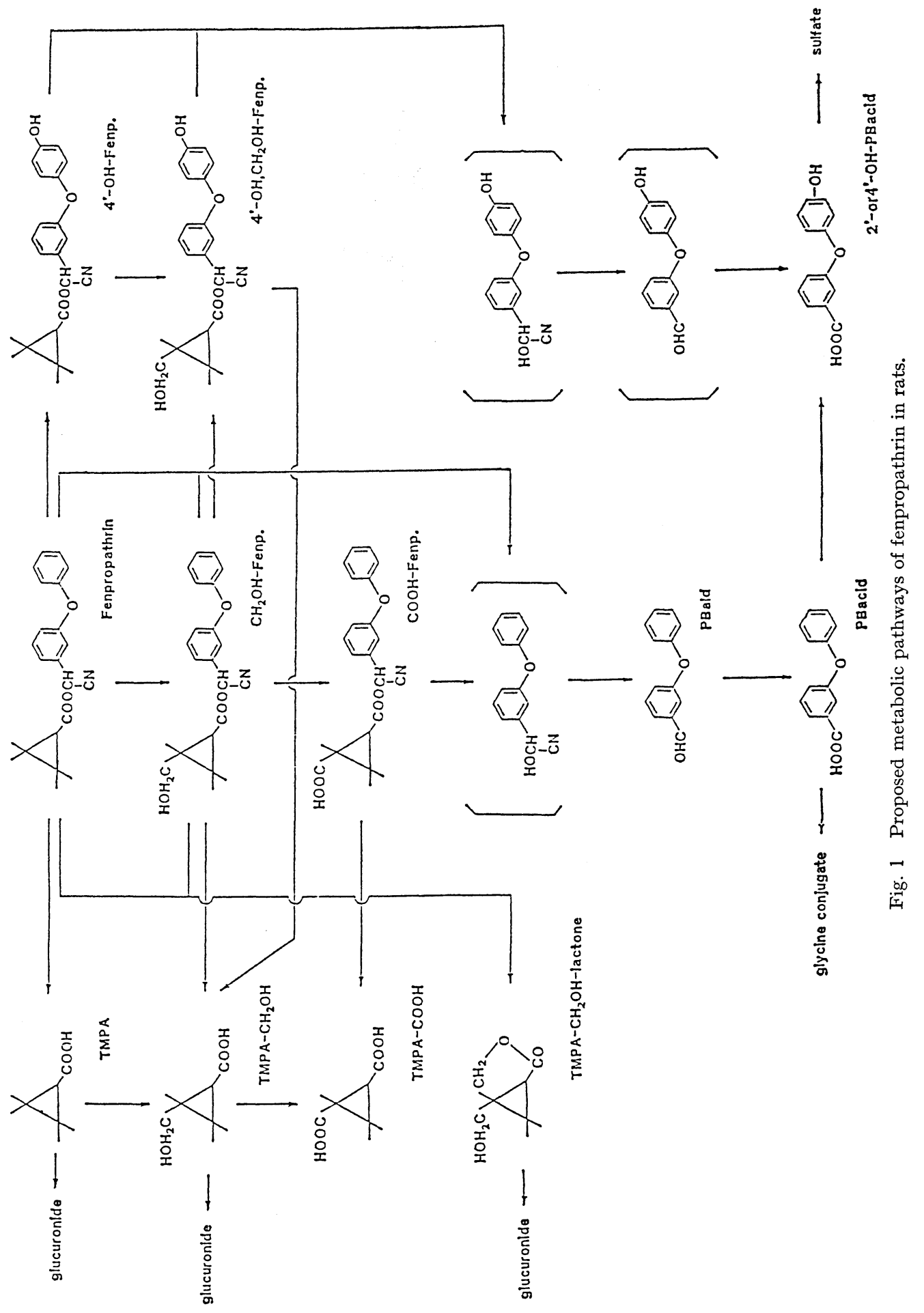


as compared with other tissues, and the residue levels in the fat were 2 to 3 times higher with the alcohol-labeling than with the acid-labeling. The residual radiocarbon in the fat of rats pretreated with unlabeled fenpropathrin was partitioned into acetonitrile and $n$-hexane. The acetonitrile layers with both the labelings contained nearly the same amount of unchanged fenpropathrin as a major ${ }^{14} \mathrm{C}$ component. However, the $n$-hexane layer with the alcohollabeling contained radioactivity approximately three times as high as that with the acid-labeling. The $n$-hexane layer was analyzed on TLC using petroleum ether-diethyl ether-acetic acid $(90 / 10 / 1)$ or by florisil chromatography using $n$-hexane-diethyl ether $(95 / 5)$ as an eluting solvent. These analyses revealed that most of the radiocarbon from both labelings was present in the triglyceride fractions. ${ }^{10)}$ These findings suggest that the alcohol moiety is likely incorporated into triglycerides to a larger extent than the acid moiety. The compound incorporated into triglycerides is assumed to be PBacid, as shown by Crayford and Hutson. ${ }^{11)}$

On the basis of the identified metabolites, the major biotransformation reactions of fenpropathrin in rats are considered to be: 1) oxidation at the methyl groups of the acid moiety and at the 2'- and 4'-positions of the alcohol moiety, 2) cleavage of the ester linkage, 3) conjugation of the resultant carboxylic acids, alcohols and phenols with glucuronic acid, sulfuric acid and glycine.

The proposed metabolic pathways for fenpropathrin in rats are given in Fig. 1. The predominant urinary metabolites derived from the acid moiety were TMPA-glucuronide and TMPA- $\mathrm{CH}_{2} \mathrm{OH}$ (trans), and other metabolites were TMPA-COOH(trans), TMPA- $\mathrm{CH}_{2} \mathrm{OH}$ (trans) and TMPA- $\mathrm{CH}_{2} \mathrm{OH}$-lactone in free form and/or glucuronide. TMPA- $\mathrm{CH}_{2} \mathrm{OH}$-lactone was not detected in the previous study. ${ }^{4}$ The major urinary metabolites derived from the alcohol moiety were PBacid in free and glycine conjugate, 4'-OH-PBacid-sulfate and 2'-OHPBacid-sulfate. These urinary metabolites from the alcohol moiety are similar to those from other pyrethroids, including fenvalerate $^{6,7)}$ phenothrin, ${ }^{8)}$ deltamethrin ${ }^{12)}$ and cypermethrin. ${ }^{13)}$ Furthermore, these results are substantially the same as those reported in the previous study on rats by Crawford and Hutson. ${ }^{4)}$

In rats treated with ${ }^{14} \mathrm{C}$-TMPA, TMPA$\mathrm{CH}_{2} \mathrm{OH}$-lactone was hardly detected, indicating that this metabolite, which was detected in rats dosed with ${ }^{14} \mathrm{C}$-fenpropathrin, might not be produced through TMPA but from fenpropathrin itself by oxidation at the geminalmethyl groups of the acid moiety and by subsequent ester cleavage followed by cyclization.

\section{REFERENCES}

1) T. Takahashi, N. Mikami, H. Yamada \& J. Miyamoto: Pestic. Sci. 16, 119 (1985)

2) N. Takahashi, N. Mikami, H. Yamada \& J. Miyamoto: Pestic. Sci. 16, 113 (1985)

3) N. Mikami, Y. Baba, T. Katagi \& J. Miyamoto: J. Agric. Food Chem. 33, 980 (1985)

4) M. J. Crawford \& D. H. Hutson: Pestic. Sci. 8, 579 (1977)

5) H. Kanamaru, T. Kamada, A. Yoshitake \& I. Nakatsuka: Radioisotopes 35, 169 (1986)

6) H. Ohkawa, H. Kaneko, H. Tsuji \& J. Miyamoto: J. Pesticide Sci. 4, 143 (1979)

7) H. Kaneko, H. Ohkawa \& J. Miyamoto: J. Pesticide Sci. 6, 317 (1981)

8) H. Kaneko, H. Ohkawa \& J. Miyamoto: J. Pesticide Sci. 6, 169 (1981)

9) H. Kaneko, H. Ohkawa \& J. Miyamoto: J. Pesticide Sci. 6, 425 (1981)

10) K. K. Carroll: J. Lipid Res. 2, 135 (1961)

11) J. V. Crayford \& D. H. Hutson: Xenobiotica 10, 349 (1980)

12) L. O. Ruzo, T. Unai \& J. E. Casida: J. Agric. Food Chem. 26, 918 (1978)

13) M. J. Crawford, A. Croucher \& D. H. Hutson: Pestic. Sci. 12, 399 (1981)

\section{要 約}

\section{Fenpropathrin(S-3206) のラットにおける代謝} 金子秀雄, 斯波久二雄, 吉武 涁, 宮本純之 Fenpropathrin[(RS)- $\alpha$-cyano-3-phenoxybenzyl 2,2,3,3tetramethylcyclopropanecarboxylate] の酸側およびアル コール側 ${ }^{14} \mathrm{C}$ 標識体を雌雄 $\mathrm{SD}$ ラットに $2.4 \sim 26.8 \mathrm{mg} / \mathrm{kg}$ の割合で 1 回経口投与すると，酸側およびアルコール側 由来の ${ }^{14} \mathrm{C}$ は投与後 7 日以内にほぼ完全に賴尿中に排泄 された。 ${ }^{14} \mathrm{C}$ 組織残留量は，両標識体ともに脂肪で若干 高かった（0.1〜1.4 ppm) ものの，他の組織ではきわめ て低かった.アルコール側標識体では酸側標識体よりも 全般的に ${ }^{14} \mathrm{C}$ 組織残留量は低かった．糞中代謝物の大部 
分はエステル結合を有する代謝物で，一方，尿中代謝物 はエステル結合が開裂を受けたものであった，主要代謝 反応はアルコール側の $2^{\prime}-$ と $4^{\prime}-$ 位と酸側の 2- と 3-位 の酸化, エステル結合の開裂拉よびグルクロン酸, 硫酸 とアミノ酸抱合体形成であった。アルコール側由来の主
要酸代謝物は 3-(4'-hydroxyphenoxy)benzoic acid の硫酸 抱合体で，投与量の $19 \sim 36 \%$ を占めた。一方，2, 2, 3, 3tetramethylcyclopropanecarboxylic acid と奋水酸化誘 導体とそれらのグルクロン酸抱合体が酸側由来の主要代 謝物であった。 